\title{
Response of Oaks and Elm to Soil Inoculations With Mycorrhizal Fungi and Rhizobacteria in a Nursery
}

\author{
Balakrishna Rao, Donald H. Marx, and Brian Jeffers
}

\begin{abstract}
Live oak (Quercus virginiana), laurel oak (Q. laurifolia), and Drake elm (Ulmus parvifolia) seedlings were grown for 1 year in $4 \mathrm{~L}$ ( 1 gal) containers and then transplanted on $3 \mathrm{~m}(10 \mathrm{ft})$ centers at a nursery in Florida, U.S. Two years later, in April 2002, ten seedlings per tree species were treated by (1) soil injection with mycorrhizal fungi and rhizobacteria; (2) drenching with rhizobacteria and soil fungi applied monthly for 5 months; (3) a combination of (1) and (2); (4) drenching with Subdue® fungicide; or (5) nontreated controls. Root growth and mycorrhizal development were measured with root ingrowth cores. After 1 year (1 April, 2003), mycorrhizal development and root growth as well as stem calipers were greater in treatments containing the mycorrhizal fungi for all three species. The rhizobacteria treatment also increased root and stem growth on Drake elm. The fungicide, Subdue, did not significantly affect mycorrhizal development or root or stem growth. There were few naturally occurring mycorrhizae on roots of trees in this nursery.
\end{abstract}

Key Words. Ectomycorrhizae; vesicular-arbuscular mycorrhizae (VAM).

Mycorrhizal fungi and rhizobacteria inhabit the fine roots of plants and impart a variety of benefits to the plant host: increased root surface area, greater absorption of water and mineral elements, increased solubility of phosphorus and other minerals, fixing of atmospheric nitrogen, reduced transplant shock, increased resistance to environmental stress, and decreased incidence of certain diseases (Waisel et al. 1996; Smith and Read 1997; Quarles 1999a,b). In exchange for these benefits the plant furnishes the mycorrhizal fungi and rhizobacteria with organic carbon from photosynthesis.

Products containing mycorrhizal fungi and rhizobacteria are commercially available (Marx et al. 2002). Increased root and ectomycorrhizal development following root inoculation with these products, with and without fertilizer, has been reported for mature northern red oak (Quercus rubra), southern live oak ( $Q$. virginiana), willow oak ( $Q$. phellos), and pecan (Carya illinoensis) growing in urban settings (Marx et al. 1995, 1997; Smiley et al. 1997; Appleton et al. 2003). Most of these studies were not designed to measure aboveground tree response because each tree received all treatments in a grid pattern over the root zone. Others reported increases in root growth and mycorrhizal development and canopy growth of northern red oak in an Ohio, U.S., nursery (Rao et al. 2000) and basswood (Tilia tomentosa) in an urban setting in France (Garbaye and Curin 1996).

Increased root and development of vesicular-arbuscular mycorrhizae (VAM) and improved canopy growth were also reported after VAM fungal and rhizobacterial inoculations of 3 to $4 \mathrm{~cm}$ (1.2 to $1.6 \mathrm{in})$ diameter transplanted maple ( $A$. freemanni), ash (Fraxinus americana), crabapple (Malus spp.), and western hackberry (Celtis occidentalis) in urban landscapes (Geist 1998) and transplanted sugar maple (Acer saccharum) (Rao et al. 2000) in a nursery. Appleton et al. (2003) reported increased root and VAM development after inoculation of $12.5 \mathrm{~cm}$ (5 in) diameter red maple (A. rubrum). In contrast, the aboveground response of live oak (Gilman 2001) and pin oak (Q. palustris) (Appleton et al. 2003) was not affected by application of these commercial products.

There appears to be a deficiency of mycorrhizae on roots of trees in urban landscapes and in many nurseries. The low incidence of naturally occurring mycorrhizae on the noninoculated trees in the aforementioned studies and in others (Morrison et al. 1993; Martin and Stutz 1994; Alves and Schmitz-Zeitz 1996; Stabler et al. 2001; Wiseman and Wells, 2005), including an intensely managed tree nursery (Sylvia et al. 1998), indicates that soil and root conditions in these landscapes can suppress mycorrhizal development. Root zone inoculations with commercial inoculants in the above inoculation studies routinely increased root and mycorrhizal development significantly over that found on noninoculated trees.

The purpose of this study was to determine the aboveground and belowground response of recently transplanted live ( $Q$. virginiana) and laurel ( $Q$. laurifolia) oaks and Drake elm (Ulmus parvifolia) to soil treatment with products containing mycorrhizal fungi and rhizobacteria in a commercial tree nursery in Florida, U.S. Live and laurel oaks form ectomycorrhizae, and elms form VAM (Marx et al. 2002).

\section{MATERIALS AND METHODS}

\section{Study Installation}

One-year-old, gallon-size container-grown seedlings of live oak, laurel oak, and Drake elm were planted in blocks by tree 
species on $3 \mathrm{~m}(10 \mathrm{ft})$ centers in February 2000 at the Davey Big Tree Nursery, Jacksonville, Florida. The soil is a sandy loam. Plastic tree shelters were placed around the stem of each tree. Trees were fertilized annually with commercial fertilizer (N15-P5-K15) at $336 \mathrm{~kg} / \mathrm{ha}(300 \mathrm{lb} / \mathrm{ac})$ using a broadcast spreader. Plots were treated twice annually with the herbicide Roundup ${ }^{\circledR}$ at label rate to control weeds in the rows. In April 2002, 50 trees of approximately the same size (height, stem diameter, and canopy spread) of each species were selected as test trees. Ten groups of five nearby trees were designated as test blocks (replicates) for each tree species. Individual trees in each of the ten blocks were randomly assigned one of five treatments. The design for each tree species was a randomized complete block with ten replicate blocks each with the following five treatments:

1. MycorTree ${ }^{\circledR}$ Injectable was injected with water at label

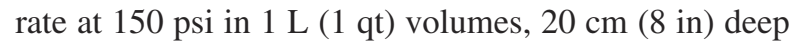
in soil, at eight locations uniformly placed in a $60 \mathrm{~cm}$ (24 in) radius area over the root zone of each treated tree. This treatment was applied once in April 2002. This inoculant contains spores of two ectomycorrhizal fungi (Pisolithus tinctorius and Scleroderma citrinum), spores of four species of VAM fungi (Entrophospora columbiana, Glomus etunicatum, G. clarum, and G. intraradices), six species of spore-forming rhizobacteria (Bacillus licheniformis, B. megaterium, B. polymyxa, B. subtilis, B. thuringiensis, and Paenibacillus azotofixans), complex carbohydrates to support microbial growth, sea kelp, and humic acids.

2. Compete ${ }^{\circledR}$ Plus and Yuccah ${ }^{\circledR}$ were applied as an $8 \mathrm{~L} \mathrm{(2}$ gal) drench each month for 5 months at label rates over a $60 \mathrm{~cm}$ (24 in) radius area over the root zone. Compete Plus contains a cocktail blend of the aforementioned six species of spore-forming rhizobacteria, plus Streptomyces griseoviridis and Trichoderma harzianum, complex carbohydrates to support microbial growth, sea kelp, and humic acids. Yuccah is a wetting agent derived from natural saponin and increases the wettability of soil, which aids in the dispersal and soil penetration of the microbes and other ingredients in the inoculant.

3. A combination of treatments 1 and 2 .

4. Subdue was applied as a soil drench at the label rate in a $60 \mathrm{~cm}(24 \mathrm{in})$ radius around each treatment tree at study installation to control fine root diseases associated with Phytophthora and Pythium species.

\section{Nontreated control.}

One root ingrowth (RIC) core, a $7.5 \mathrm{~cm}$ (3 in) diameter $\times$ $20 \mathrm{~cm}$ (8 in) long perforated plastic core (Marx et al. 1997), was placed about $20 \mathrm{~cm}(8 \mathrm{in})$ from the stem of each test tree and $20 \mathrm{~cm}$ (8 in) deep in the soil. Each RIC was filled with root-free soil collected from around test trees. A total of 150 RICs were installed.
All trees in treatment groups 1,4 , and 5 were drenched with $8 \mathrm{~L}$ ( $2 \mathrm{gal})$ of water over a $60 \mathrm{~cm}$ (24 in) radius of the root zone each month for 5 months to standardize the water applied in treatments 2 and 3.

In August 2002, all trees were pruned to shape the canopy.

\section{Study Assessments}

Stem diameters were taken $10 \mathrm{~cm}$ (4 in) above the root flare on the north side of each test tree at study installation in April 2002 and in April 2003. In April 2003, RICs were removed by cutting roots from around the outside of each RIC. Soil and roots in each RIC were removed and roots were separated from the soil over a $4 \mathrm{~mm}$ mesh $(0.16$ in) screen. Roots were wrapped in moist paper towels, placed in a labeled Ziploc plastic bag, and stored in coolers with freezer tabs. One day later they were refrigerated. After 4 days, fine roots $2 \mathrm{~mm}$ diameter (0.08 in) or less were separated from roots of various weeds, washed, and weighted (fresh weight). The fine roots of both oak species were visually assessed (5x magnification) for ectomycorrhizae, and the elm roots were assessed for VAM development after standard root clearing and staining and microscope procedures (Kormanik and McGraw 1982).

All data were statistically analyzed using standard analysis of variance, and significantly different $(P=0.05)$ means were further separated using the Duncan multiple range test.

\section{RESULTS}

Survival of the test trees was not affected by treatment. All of the live oaks survived and 44 of the 50 test trees (88\%) of laurel oak and Drake elm survived.

\section{Live Oak}

Measurements of root growth were confounded by weed roots in the RICs. Many ectomycorrhizal roots were lost during their physical separation from the weed roots. Fine root production was significantly greater for trees treated with the mycorrhizal fungi with and without the rhizobacteria plus Yuccah than the other treatments (Table 1). Many of the ectomycorrhizae were formed by P. tinctorius and S. citrinum. These specific ectomycorrhizae were identified based on their color, morphology, and mycelial strand features. These morphotypes were not observed on noninoculated trees. Although the percentage of fine roots colonized by the introduced fungi was low, significantly more were observed on the fine roots of trees in the mycorrhizal fungi treatment with and without the rhizobacteria and Yuccah. The incidence of naturally occurring ectomycorrhizae was very low. Compared to noninoculated trees, Subdue and the rhizobacteria treatments had no effect on ectomycorrhizal development of live oak.

The stem diameter of trees receiving the mycorrhizal fungi and rhizobacteria treatments was significantly greater than 
Table 1. Initial and first-year response of live oak trees to mycorrhizal fungal injection (MycorTree ${ }^{\circledR}$ Injectable) and rhizobacterial (Compete ${ }^{\circledR}$ Plus and Yuccah $^{\circledR}$ ) soil treatments.

\begin{tabular}{llllll}
\hline & & \multicolumn{3}{c}{ After 1 year } \\
\cline { 3 - 6 } Treatment & Initial dia. $(\mathrm{cm})$ & Fine roots $(\mathrm{g})$ & \% ecto. & Stem dia. $(\mathrm{cm})$ & \% stem dia. increase* \\
\hline Mycor & $2.9 \mathrm{a}$ & $6.2 \mathrm{ab}$ & $16 \mathrm{a}$ & $6.1 \mathrm{ab}$ & $116 \mathrm{a}$ \\
Mycor + bacteria & $2.9 \mathrm{a}$ & $7.3 \mathrm{a}$ & $19 \mathrm{a}$ & $6.2 \mathrm{a}$ & $115 \mathrm{a}$ \\
Bacteria $_{\text {Subdue }}^{\circledR}$ & $2.8 \mathrm{a}$ & $3.4 \mathrm{~b}$ & $6 \mathrm{~b}$ & $5.5 \mathrm{ab}$ & $100 \mathrm{ab}$ \\
Control $^{\circledR}$ & $3.1 \mathrm{a}$ & $4.0 \mathrm{ab}$ & $6 \mathrm{~b}$ & $5.6 \mathrm{ab}$ & $81 \mathrm{~b}$ \\
\hline
\end{tabular}

$* \%$ Increase $=$ (first yr. - initial measurements)/initial measurement.

the control trees (Table 1). However, due to wide variation in initial stem diameter (although not significant), an examination of the percentage increase in stem diameters showed that trees treated with the mycorrhizal fungi with and without the rhizobacteria and Yuccah were significantly larger than trees treated with Subdue or nontreated controls.

\section{Laurel Oak}

Accurate measurements of oak root growth were severely hampered by weed roots in the RICs. As with the live oaks, many roots were lost during their physical separation from weed roots. Treatments with any microbial product did not affect fine root growth (Table 2). As with the live oak seedlings, the number of naturally occurring ectomycorrhizae was very low. Treatments did not significantly affect stem diameters; however, the percentage increase in stem diameters was significantly larger on trees treated with the mycorrhizal fungi with and without the rhizobacteria with Yuccah.

\section{Drake Elm}

The weed competition in the elm plots was severe. However, because VAM roots are smaller than ectomycorrhizae, fewer VAM were lost during their physical separation from weed roots. The mycorrhizal fungi with and without rhizobacteria and Yuccah improved fine root growth by nearly threefold over elms treated with Subdue and nontreated controls (Table 3). The mycorrhizal fungi also increased VAM development by nearly threefold over elms not treated with the mycorrhizal fungi. The results show that treatments such as rhizobacteria and Yuccah can increase fine root growth but not increase VAM development on these fine roots. Unless adequate inocula of the VAM fungi are available in the soil, either naturally or by artificial introduction, they will be slow in colonizing these new roots. On this site, naturally occurring VAM fungi were obviously very low. Subdue did not affect VAM development.

Initial stem diameters of the elms in the Subdue treatment group were, by chance, significantly larger than trees in the mycorrhizal fungi and the rhizobacteria treatment groups. The percentage increases in stem diameters were greater for the trees receiving the three microbial treatments than in the nontreated controls. Stem measurements of elms in the Subdue treatment group were not different from those receiving the three microbial treatments.

\section{DISCUSSION}

MycorTree Injectable and Compete Plus contain a cocktail mix of six rhizobacterial species and the same complex carbohydrates, sea kelp, and humic acid. Compete Plus also contains $S$. griseoviridis and $T$. harzianum. The only treatment that consistently increased fine root growth, mycorrhizal development, and stem growth for trees in this study was the injected mycorrhizal fungi. The application of both MycorTree Injectable and Compete Plus with Yuccah did not consistently improve the growth of any tree species over that of MycorTree Injectable alone. This suggests that additional

Table 2. Initial and first-year response of laurel oak trees to mycorrhizal fungal injection (MycorTree ${ }^{\circledR}$ Injectable) and rhizobacterial (Compete ${ }^{\circledR}$ Plus and Yuccah ${ }^{\circledR}$ ) soil treatments.

\begin{tabular}{llllll}
\hline & & & \multicolumn{3}{c}{ After 1 year } \\
\cline { 3 - 6 } Treatment & Initial dia. $(\mathrm{cm})$ & Fine roots $(\mathrm{g})$ & $\%$ ecto. & Stem dia. $(\mathrm{cm})$ & $\%$ stem dia. increase* \\
\hline Mycor & $2.1 \mathrm{a}$ & $2.0 \mathrm{a}$ & $4 \mathrm{a}$ & $4.8 \mathrm{a}$ & $128 \mathrm{a}$ \\
Mycor + bacteria & $2.0 \mathrm{a}$ & $2.7 \mathrm{a}$ & $6 \mathrm{a}$ & $4.2 \mathrm{a}$ & $110 \mathrm{a}$ \\
Bacteria $_{\text {Subdue }}^{\circledR}$ & $2.5 \mathrm{a}$ & $2.4 \mathrm{a}$ & $5 \mathrm{a}$ & $4.7 \mathrm{a}$ & $88 \mathrm{~b}$ \\
Control $^{\circledR}$ & $2.5 \mathrm{a}$ & $1.3 \mathrm{a}$ & $2 \mathrm{~b}$ & $4.4 \mathrm{a}$ & $76 \mathrm{~b}$ \\
\hline
\end{tabular}

$* \%$ Increase $=$ (first yr. - initial measurements)/initial measurement. 
Table 3. Initial and first-year response of Drake elm trees to mycorrhizal fungal injection (MycorTree ${ }^{\circledR}$ Injectable) and rhizobacterial (Compete ${ }^{\circledR}$ Plus and Yuccah ${ }^{\circledR}$ ) soil treatments.

\begin{tabular}{|c|c|c|c|c|c|}
\hline \multirow[b]{2}{*}{ Treatment } & \multirow[b]{2}{*}{ Initial dia. $(\mathrm{cm})$} & \multicolumn{4}{|c|}{ After 1 year } \\
\hline & & Fine roots $(\mathrm{g})$ & $\%$ VAM & Dia. $(\mathrm{cm})$ & $\%$ stem dia. increase* \\
\hline Mycor & $1.6 \mathrm{~b}$ & $13.3 \mathrm{a}$ & $22 \mathrm{a}$ & $4.5 \mathrm{~b}$ & $181 \mathrm{a}$ \\
\hline Mycor + bacteria & $1.7 \mathrm{ab}$ & $11.4 \mathrm{a}$ & $27 \mathrm{a}$ & $4.8 \mathrm{ab}$ & $182 \mathrm{a}$ \\
\hline Bacteria & $1.6 \mathrm{~b}$ & $15.2 \mathrm{a}$ & $8 \mathrm{~b}$ & $4.3 \mathrm{ab}$ & $167 \mathrm{a}$ \\
\hline Subdue ${ }^{\circledR}$ & $2.1 \mathrm{a}$ & $3.0 \mathrm{~b}$ & $9 \mathrm{~b}$ & $5.2 \mathrm{a}$ & $148 \mathrm{ab}$ \\
\hline Control & $1.8 \mathrm{ab}$ & $4.4 \mathrm{~b}$ & $6 \mathrm{~b}$ & $4.1 \mathrm{~b}$ & $128 \mathrm{~b}$ \\
\hline
\end{tabular}

$* \%$ Increase $=$ (first yr. - initial measurements)/initial measurement.

rhizobacteria and the other ingredients did not add to tree growth.

\section{CONCLUSIONS}

This nursery trial showed that the introduction of mycorrhizal fungi to the root zone improved ectomycorrhizal development on live and laurel oaks and VAM and root development on Drake elm. These were correlated with increased tree stem growth in all species. Additional rhizobacteria did not consistently affect root or stem growth in these tree species. Subdue drench did not affect mycorrhizal development or root growth and did not affect stem growth on any tree species. The occurrence of native ectomycorrhizae and VAM was very low on trees in this nursery.

Acknowledgments. We thank Selina Marx and Teresa Parrish of Plant Health Care, Inc., and the crew at Davey Big Tree Nursery, Jacksonville, FL, for field assistance with this research project.

\section{LITERATURE CITED}

Alves, S.A., and D. Schmitz-Zeitz. 1996. Study of the mycorrhizal status of fine roots of urban oaks. Mitteilungen der Versuchsanstalt fur Pilzanbau der Landwirtschaftskammer Reinland 18:63-70.

Appleton, B., J. Koci, S. French, et al. 2003. Mycorrhizal fungal inoculation of establishes street trees. Journal of Arboriculture 29:107-110.

Garbaye, J., and J.L. Curin. 1996. Effects of ectomycorrhizal inoculation at planting on growth and foliage quality of Tilia tomentosa. Journal of Arboriculture 22:29-33.

Geist, S. 1998. Mycorrhizal inoculation and fertilizer effects on roots of newly planted trees. Tree Leaves 24:4.

Gilman, E.F. 2001. Effect of nursery production method, irrigation, and inoculation with mycorrhizae forming fungi on establishment of Quercus virginiana. Journal of Arboriculture 27:30-38.

Kormanik, P.K., and A.C. McGraw. 1982. Qualifications of vesicular-arbuscular mycorrhizae in plant roots. In N.C. Schenck (Ed.). Methods and Principles of Mycorrhizal Research. American Phytopathological Society, St. Paul, MN, pp. 37-45.
Marx, D.H., M.D. Pettway, and R.D. Mellick. 1995. Study focuses on ectomycorrhizal fungi. Tree Care Industry (August):29-32.

Marx, D.H., M. Murphy, T. Parrish, et al. 1997. Root response of mature Live oaks in coastal South Carolina to root zone inoculations with mycorrhizal fungi. Journal of Arboriculture 23:257-263.

Marx, D.H., L.F. Marrs, and C.E. Cordell. 2002. Practical use of mycorrhizal fungal technology in forestry, reclamation, arboriculture, agriculture, and horticulture. Dendrobiology 47:27-40.

Martin, C.A., and J.C. Stutz. 1994. Growth of Argentine mesquite inoculated with vesicular-arbuscular mycorrhizal fungi. Journal of Arboriculture 20:134-139.

Morrison, S.J., P.A. Nicholl, and P.R. Hicklenton. 1993. VA mycorrhizal inoculation of landscape trees and shrubs growing under high fertilizer conditions. Journal of Environmental Horticulture 11:64-71.

Quarles, W. 1999a. Plant disease biocontrol and VAM fungi. The IPM Practitioner 21(4):1-9.

- 1999b. Plant disease biocontrol and Ectomycorrhizae. The IPM Practitioner 21(9):1-11.

Rao, B., B. Jeffers and Burkhart, L. 2000. Effects of fertilization and mycorrhizae on newly planted red oaks and sugar maples. In: Siewart A. et al. (Eds.). Tree and Shrub Fertilization: International Conference on Tree and Shrub Fertilization. Fairlawn, OH, May 2000, pp. 105-120.

Smiley, E.T., D.H. Marx, and B.R. Fraedrich. 1997. Ectomycorrhizal fungus inoculation of established residential trees. Journal of Arboriculture 23:113-115.

Smith, S.E., and D.J. Read. 1997. Mycorrhizal Symbiosis. Academic Press, Harcourt Brace, NY, 605 pp.

Stabler, L.B., C.A. Martin, and J.C. Stutz. 2001. Effect of urban expansion on arbuscular mycorrhizal fungal mediation of landscape tree growth. Journal of Arboriculture 27:193-202.

Sylvia, D.M., A. Alagely, D. Kent, and R. Mecklenburg. 1998. Mycorrhizae of landscape trees produced in raised beds and containers. Journal of Arboriculture 24: 308-314. 
Waisel, Y., A. Eshel, and U. Kafkafi. 1996. Plant Roots: the Hidden Half. Marcel Dekker, NY, 1002 pp.

Wiseman, P.E., and C. Wells. 2005. Soil inoculum potential and arbuscular mycorrhizal colonization of Acer rubrum in forested and developed landscapes. Journal of Arboriculture 31:296-301.

\section{Balakrishna Rao (corresponding author) Manager of Research and Technical Development The Davey Tree Expert Company \\ PO Box 5193 \\ 1500 North Mantua Street \\ Kent, OH 44240-5193, U.S. \\ brao@davey.com}

\section{Brian Jeffers}

Project Supervisor

The Davey Tree Expert Company

PO Box 5193

1500 North Mantua Street

Kent, OH 44240-5193, U.S.

\section{Donald H. Marx \\ Chief Scientist \\ Plant Health Care, Inc. \\ 775 Eddings Point Road \\ Frogmore, SC 29920, U.S.}

Résume. Des semis de chêne vert (Quercus virginiana), de chêne à feuilles de laurier (Quercus laurifolia) et d'orme chinois (Ulmus parvifolia) ont été mis en croissance pendant un an dans des contenants de $4 \mathrm{~L}$ et par la suite transplantés à $3 \mathrm{~m}$ centre à centre dans une pépinière de Floride. Deux ans plus tard en avril 2002, 10 semis par espèce d'arbre ont été traités selon l'une des manières suivantes: 1) par injection dans le sol de mycorhizes et de rhizobactéries, 2) par mouillage du sol mensuellement pendant cinq mois de mycorhizes et de rhizobactéries, 3) par une combinaison des traitements 1 et 2,4) par mouillage avec le fongicide Subdue ${ }^{\circledR}$, et 5) sans traitement (groupe témoin). La croissance racinaire et le développement des mycorhizes ont été mesurés par l'extraction de carottes de racines. Après un an ( $1^{\mathrm{er}}$ avril 2003), le développement des mycorhizes et la croissance racinaire, tout comme le calibre de la tige, étaient plus élevés pour toutes les espèces ayant fait l'objet de traitements avec des mycorhizes. Les traitements à l'aide de rhizobactéries ont aussi accrû la croissance des racines et de la tige chez l'orme chinois. Le fongicide Subdue ${ }^{\circledR}$ n'a pas affecté significativement le développement des mycorhizes ainsi que la croissance des racines et de la tige. La mycorhization naturelle était peu présente sur les racines des arbres de cette pépinière.

Zusammenfassung. In einer Baumschule in Florida wurden die Sämlinge von Lebenseiche, Lobeereiche und Drachenulme für 1 Jahr in einen 4-Liter-Container gepflanzt und dann in $3 \mathrm{~m}$ breite Zentren verpflanzt. 2 Jahre später im April 2002 wurden 10 Sämlinge pro Baumart entweder mit (1) einer Bodeninjektion mit Mycorrhiza und Rhizobakteria, (2) einer Applikation über 5 Monate mit Rhizobakteria und Bodenpilzen, (3) einer Kombination von 1 und 2, (4) Fungizidapplikation behandelt, (5) ist die unbehandelte Kontrollgruppe. Das Wurzelwachstum und die Entwicklung des Mycorrhiza wurden mit Wurzelkernen gemessen. Nach einem Jahr (April 2003) war das Mycorrhiza- und Wurzelwachstum ebenso wie die Stammumfänge innerhalb der Behandlungen mit der MycorrhizaBehandlung für alle drei Baumarten größer. Die RhizobakterienBehandlung verstärkte auch das Wurzel- und Stammwachstum der Drachenulme. Das Fungizid beeinflusste die Mycorrhizaentwicklung und Wurzel- und Stammwachstum nicht besonders. In dieser Baumschule wurden nur wenige natürlich vorkommende Mycorrhiza an Wurzeln entdeckt.

Resumen. Brinzales de encinos (Quercus virginiana), (Q. laurifolia) y olmo (Ulmus parvifolia) crecieron por un año en contenedores de 4 litros (1 gal.) y luego fueron trasplantados a distancias de 3 metros (10 pies) en un vivero en Florida. Dos años después, en Abril de 2002, 10 brinzales por especie fueron tratados con: (1) inyección al suelo con hongo micorrízico y rizobacteria, (2) zanjas con rizobacteria y hongos aplicados al suelo mensualmente por cinco meses, (3) una combinación de (1) y (2), (4) zanjeo con fungicida Subdue ${ }^{\circledR}$ o (5) controles no tratados. Se midió el crecimiento de las raíces y el desarrollo micorrízico con probetas de crecimiento de raíces. Después de un año (Abril 1, 2003), el desarrollo micorrízico y el crecimiento de las raíces, así como los diámetros de los tallos fueron mayores en los tratamiento con hongo micorrízico para todas las tres especies de árboles. El tratamiento de rizobacteria también incrementó el crecimiento de raíces y tallos en el olmo. El fungicida Subdue ${ }^{\circledR}$ no afectó significativamente el desarrollo micorrízico, el crecimiento de las raíces o el tallo. Las micorrizas naturales fueron escasas en las raíces de los árboles de este vivero. 